\title{
Abkürzungen für die meistzitierten Primärtexte
}

\author{
$A D \quad$ L'Amérique découverte (Laureau) \\ CCAD Christophe Colomb, ou l'Amérique découverte (Bourgeois) \\ COL La Colombiade (Du Boccage) \\ DINO De invento Novo Orbe (Peramás) \\ INC Les Incas (Marmontel) \\ NM Le Nouveau Monde (Lesuire) \\ $L A \quad$ Lettres sur l'Atlantide de Platon (Bailly) \\ LP Libro de las Profecías (Columbus)
}


